
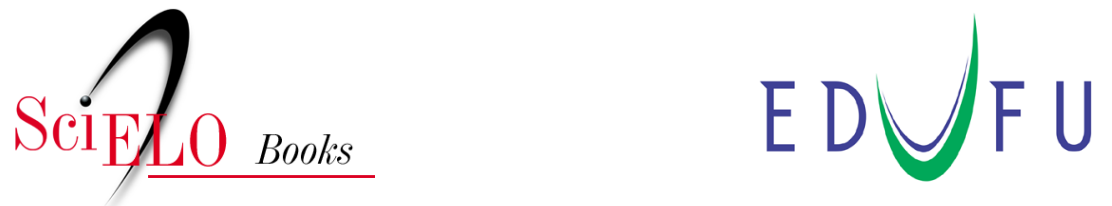

\title{
A perspectiva pedagógica de Antonio Gramsci
}

\author{
Deise Rosalio Silva
}

\section{SciELO Books / SciELO Livros / SciELO Libros}

SILVA, D.R. A perspectiva pedagógica de Antonio Gramsci. In: BOTO, C., ed. Clássicos do pensamento pedagógico: olhares entrecruzados [online]. Uberlândia: EDUFU, 2019, pp. 141-170. História, Pensamento, Educação collection. Novas Investigações series, vol. 9. ISBN: 978-65-5824-027-3. Available from: http://books.scielo.org/id/fjnhs/pdf/boto-9786558240273-08.pdf. https://doi.org/10.14393/edufu-978-85-7078-472-8.

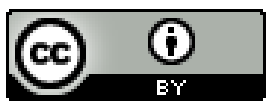

All the contents of this work, except where otherwise noted, is licensed under a Creative Commons Attribution 4.0 International license.

Todo o conteúdo deste trabalho, exceto quando houver ressalva, é publicado sob a licença Creative Commons Atribição 4.0.

Todo el contenido de esta obra, excepto donde se indique lo contrario, está bajo licencia de la licencia Creative Commons Reconocimento 4.0. 


\title{
A perspectiva pedagógica de Antonio Gramsci
}

\author{
Deise Rosalio Silva
}

\section{Introdução}

O objetivo deste texto é identificar o discurso de Antonio Gramsci (1981-1937) sobre educação e sua atualidade teórica, analisando, principalmente, a produção realizada no cárcere. Gramsci ansiava pela constituição de um plano de ação capaz de alterar a estrutura político-econômica da sociedade. Nesse sentido, a dimensão cultural e educativa ocupa uma posição destacada na sua reflexão sobre a transformação social. A educação e a cultura são, na ótica gramsciana, as peças fundamentais para a constituição de um novo homem: autônomo, consciente, crítico, capaz de criar novas relações e as demais condições necessárias para a superação da estratificação social em prol da edificação de uma outra ordem econômica e política, não mais pautada pela desigualdade social. Para isso, o alcance da hegemonia seria o primeiro passo, só atingido quando a concepção de mundo compatível com tal plano de transformação fosse majoritária na sociedade. Eis - nos escritos gramscianos - o grande papel ocupado pela figura do intelectual - ator público disseminador de ideologias - e da educação no processo de luta política pela emancipação do homem. Esse processo requereria, contudo, uma ampla formação humanista, 
integral, crítica, criativa, capaz de agregar trabalho intelectual e trabalho manual, sendo que sua maior expressão estaria no ideal da "escola única”. Exatamente por isso, Gramsci era contrário a qualquer tipo de "rebaixamento" na educação e acreditava que certa dose de rigor e diretividade eram aspectos irrenunciáveis para o alcance da mais ampla formação do sujeito.

\section{Na trilha de Gramsci ${ }^{1}$}

Antonio Gramsci nasceu em 1891, em Ales, ilha da Sardenha, na Itália, e faleceu em 1937. Político, estudioso, pensador marxista, construiu sua relevante obra política em meio a substanciais transformações e inflexões definidoras do século $\mathrm{XX}$, tais como a Primeira Guerra Mundial, a Revolução Socialista na Rússia, o surgimento de partidos comunistas em diversos países. Gramsci protagonizou a criação do Partido Comunista Italiano e viveu o fracasso das tentativas socialistas no Ocidente, além da ascensão e repressão fascista, que determinou sua prisão por vinte anos nos cárceres de Mussolini. Permaneceu por onze anos nessa condição e faleceu no dia 27 de abril de 1937 na Clínica Quisisana, em Roma, uma semana após ter acabado sua pena, por complicações de uma hemorragia cerebral.

Gramsci é oriundo desse cenário e reage diante dos acontecimentos que marcaram a Itália no fim do século XIX. Sua produção surgiu em resposta a todo o contexto da época. Abordou muitos aspectos em seus estudos, tendo escrito sobre diversos assuntos, desenvolvendo uma leitura particular sobre eles e/ou criando novos conceitos.

Sua produção compreende artigos escritos em diversos

${ }^{1}$ Texto realizado com base na dissertação de mestrado: SILVA, Deise Rosalio. Intelectuais, cultura e escola única no pensamento politicopedagógico de Antonio Gramsci. 2010. 267f. Dissertação (Mestrado em Educação) - Faculdade de Educação, Universidade de São Paulo, São Paulo, 2010. 
periódicos socialistas realizados durante sua atuação militante. Dos 33 cadernos que escreveu enquanto esteve preso, 29 foram editados postumamente por temas e, mais tarde, de acordo com a disposição escrita por Gramsci, como Cadernos do cárcere ${ }^{2}$.

Gramsci caracteriza um importante lugar para a educação como eixo motor da ação necessária à mudança do sistema social vigente.

Nesse sentido, confere posição de destaque à figura do intelectual que, em sua acepção, seria todo sujeito histórico-crítico que influi de alguma maneira no trato com outros sujeitos na sociedade, propagando ou combatendo uma visão de mundo. Para Gramsci, era urgente a realização de um coerente e profundo projeto educativo, sem o qual jamais se realizaria uma "reforma intelectual e moral".

\section{A educação e a cultura na formação dos sujeitos}

O pedagógico para Gramsci está muito além da ação escolar.É evidente que a escola desempenha um papel de extrema importância na formação dos sujeitos, mas não é o único meio de exercício do trabalho pedagógico.

Gramsci, no Caderno 1033, afirma:

Mas a relação pedagógica não pode ser limitada às relações especificamente "escolares", através das quais as novas gerações entram em contato com as antigas e absorvem suas experiências e seus valores historicamente necessários, "amadurecendo" e desenvolvendo uma própria personalidade, histórica e culturalmente superior. Essa relação existe em toda a sociedade no seu conjunto e em todo indivíduo com relação aos outros indivíduos, entre setores intelectuais e não intelectuais, entre governantes e governados, entre elites e seguidores,

${ }^{2}$ Utilizarei como referência principal a edição original crítica dessa obra: GRAMSCI, Antonio. Quaderni del carcere. Edizione critica. 3. ed. A cura di Valentino Gerratana. Torino: Einaudi. 4 v.

${ }^{3}$ Todas as traduções de textos escritos originalmente em italiano são minhas. 
entre dirigentes e dirigidos, entre vanguardas e corpos de exército. (Gramsci, 2007, p. 1.331).

Depreende-se por esse trecho que a questão formativa acompanha outras esferas sociais e, portanto, está indissociavelmente ligada à questão cultural.

A ênfase que Gramsci dá à criação de espaços de cultura não minimiza o papel da escola, como destaca no Caderno 19: "A atividade escolar, em todos os seus graus, tem uma importância enorme também econômica, para os intelectuais de todos os graus" (Gramsci, 2007, p. 2.047).

Segundo Dal Ri e Vieitez: "somente o sistema escolar desenvolve esse trabalho de modo regular, sistemático, reflexivo e apoiado nos conhecimentos universais das ciências ou em variantes desses conhecimentos" (Dal Ri; Vieitez, 2009, p. 257).

A esse respeito, no Caderno 12, podemos encontrar a seguinte referência feita por Gramsci:

A escola é o instrumento para elaborar os intelectuais de vários graus. A complexidade da função intelectual nos diversos Estados se pode medir objetivamente pela quantidade de escolas especializadas e pela sua hierarquia: quanto mais extensa é a "área" escolar e quanto mais numerosos os "graus" "verticais" da escola, tanto é mais complexo o mundo cultural, a civilização, de um determinado Estado. (Gramsci, 2007, p. 1.517).

A escola apresenta uma posição balizadora do modo como se estabelecem as relações sociais; é definidora, portanto, da roupagem e, também, de certo modo, da expressão de uma sociedade.

Ele atribui fundamental importância à questão escolar, inclusive o projeto de uma "escola unitária" é sua maior bandeira no âmbito da "elevação cultural e moral" da classe trabalhadora.

Gramsci (2007, p. 1.546) afirmava que o estudo deveria ser 
"desinteressado, não deve ter finalidades práticas imediatas ou muito imediatas, deve ser formativo ainda que 'instrutivo', isto é, rico de noções concretas". Opunha-se a dualidade escolar. A escola precisava deixar de ser um privilégio. Desse modo, tecia sua crítica à educação profissional da época:

A escola profissional não deve se tornar uma incubadora de pequenos monstros aridamente instruídos para um ofício, sem ideias gerais, sem cultura geral, sem alma, mas só com o olho certeiro e a mão firme. É também através da cultura profissional que se pode fazer com que do menino brote homem, desde que essa seja uma cultura educativa e não apenas informativa. (Gramsci, 1964, p. 227).

As escolas existentes formavam para o trabalho, mas não iam além da preparação de executores. Não exploravam a constituição de homens que dominassem todos os saberes que envolviam a técnica, que compreendessem os limites daquele campo e desempenhassem o máximo das possibilidades existentes naquele trabalho.

Gramsci não partilhava da ideia de segregação entre instrução e educação, pois atribuía um valor formativo à primeira, desde que não fosse encarada como uma recepção vazia de conteúdos. Em suas palavras:

Não é completamente exato que a instrução não seja também educação: a insistência exagerada nessa distinção foi um grave erro da pedagogia idealista, cujos efeitos já se vêem na escola reorganizada por esta pedagogia. Para que a instrução não fosse igualmente educação, seria necessário que o aluno fosse meramente passivo, um "recipiente mecânico" de noções abstratas, o que é absurdo, além de ser "abstratamente" negado pelos defensores da pura educatividade precisamente contra a mera instrução mecanicista. (Gramsci, 2007, p. 1.541-1.542). 
Esse trecho elucida elementos importantes da concepção gramsciana de educação. Gramsci não concebe o aluno como uma "tábula rasa"; ele discorda completamente dessa acepção. Vê o aluno como um sujeito-histórico que traz em si o peso e o aprendizado das experiências vividas. E é com esse aluno que a escola deve trabalhar. As instituições de ensino devem empreender esforços para possibilitar que os alunos tenham contato com a mais completa gama de conhecimentos - dos mais simples aos mais complexos - empreendidos pelo homem, abordando-os sempre de modo que a reflexão, a crítica e a criação sejam estimuladas.

Nesse sentido, Gramsci defendia o elo entre a escola e a vida, e entre a instrução e a educação. A educação não podia ser rebaixada, nivelada por baixo para atingir a todos. Pelo contrário, justamente pelo caráter unitário, a escola tinha que implementar todo o rigor e toda a complexidade de conteúdos e saberes acumulados pela humanidade, para que houvesse condições da ampliação cultural e moral dos sujeitos. Era preciso emergir "uma escola unitária na qual o trabalho e a teoria estão intimamente unidos” (Gramsci, 2007, p. 1.183).

Em suas palavras:

Escola única inicial de cultura geral, humanística, formativa, que equilibre de modo justo o desenvolvimento da capacidade de trabalhar manualmente (tecnicamente, industrialmente) e o desenvolvimento da capacidade do trabalho intelectual (Gramsci, 2007, p. 1.531).

Gramsci não se referia à escola destinada a formar profissionais em técnicas diversas, mas a uma escola única que possibilitasse a apreensão de noções (evidentemente também técnicas, mas não reduzível apenas a isso) de todas as ciências, das artes, do direito, da cidadania e da cultura. E não se tratava apenas de instrução geral, básica.

Gramsci não deslegitima a erudição, o rigor a que os sujeitos precisam ser submetidos, pelo contrário, denota a crucialidade 
atribuída a uma educação que possibilite o desenvolvimento máximo das capacidades também intelectuais dos sujeitos.

O Estado deveria ser o mantenedor da escola, mas não o seu controlador. Sua obrigação precisava estar calcada na garantia do acesso, na permanência em uma instituição que oferecesse um ensino de qualidade, mas não no controle do que era ensinado e de que modo.

Por esse motivo, "a inteira função da educação e formação das novas gerações se transforma de privada em pública, porque só assim ela pode envolver todas as gerações sem divisões de grupos ou castas" (Gramsci, 2007, p. 1.534).

\section{O lugar da pedagogia gramsciana: para além da espontaneidade e do dogmatismo}

Coerente com a sua visão histórica, Gramsci era contrário a todo tipo de inatismo.

Em uma carta destinada a sua mulher Giulia, datada de $1^{\circ}$ de agosto de $1932^{4}$, tratando dos apontamentos dela sobre as possíveis “inclinações” vocacionais de seus filhos Giuliano e Délio, Gramsci aborda a questão da formação integral, explicitando a sua concepção de homem:

Digo-te, na verdade, que não creio nessas inclinações genéricas assim precoces e que tenho pouca confiança em tua capacidade de observar as suas tendências quanto a uma orientação profissional. Creio que em cada um deles subsistem todas as tendências, como em todas as crianças, seja em relação à prática, seja em relação à teoria ou à fantasia e que antes seria justo guiá-los, neste sentido, para um equilíbrio harmônico de todas as faculdades intelectuais e práticas, as quais terão como especializar-se no devido tempo, com base numa

${ }^{4} \mathrm{~A}$ carta escrita em 14 de dezembro de 1931, também destinada à mulher Giulia,já trazia essa discussão. É também nessa correspondência que afirma "A questão escolar me interessa muitíssimo" (Gramsci, 1987b, p. 68). 
personalidade vigorosamente formada em sentido global e integral. (Gramsci, 1987b, p. 130-131).

Dessa forma, o caráter sócio-histórico da concepção gramsciana de homem é reafirmado. O homem é fruto da sua história e da história daqueles que o antecederam.

Se o trabalho desenvolvido pelos antepassados reflete e forma os homens do presente, da mesma forma o trabalho de hoje pautará o homem de amanhã. $\mathrm{O}$ passado o constitui, mas o futuro lhe cabe e a educação tem o presente para isso, para formar o futuro por intermédio do homem que desenvolverá.

Dessa forma, torna-se compreensível a afirmação gramsciana de que a escola deve formar hábitos morais e disciplinares, afinal,

Lida-se com adolescentes, aos quais é preciso fazer com que adquiram certos hábitos de diligência, de exatidão, de compostura até mesmo física, de concentração psíquica em determinados assuntos, que só podem adquirir mediante uma repetição mecânica de atos disciplinados e metódicos. Um estudioso de quarenta anos seria capaz de passar dezesseis horas seguidas numa mesa de trabalho se, desde menino, não tivesse assimilado, por meio da coação mecânica, os hábitos psicofísicos apropriados? (Gramsci, 2007, p. 1.544).

Gramsci atribuía importância à disciplina e, mais do que isso, julgava que era preciso garantir o seu desenvolvimento e hábito como um requisito no processo de ensino-aprendizagem. Afinal, pensar o processo educativo sem disciplina seria o mesmo que pautar uma educação espontânea e casual e não uma educação intencional e diretiva para o desenvolvimento intelectual, moral e cultural dos sujeitos, como era o ansiado por Gramsci.

Oliveiros S. Ferreira (1986, p. 247) destaca que

A coerção, no sentido de Gramsci, é legítima porque faz parte da 
própria natureza da relação pedagógica, mesmo a moderna e aquela voltada ao desenvolvimento das potencialidades críticas e criativas do aluno. Ela é inerente à relação pedagógica não como escravidão, mas como responsabilidade, vale dizer como participação interiorizada nos valores grupais, o indivíduo aceitando a restrição ao livre arbítrio por intuir, quando não saber, ser este é o caminho adequado à integração no tipo social criado pelo panorama ideológico da geração em que vive. Em outras palavras, é o canal social apto a cada um poder realizar dentro de si a adequação de sua liberdade à lei e à norma social, criando condições para sua ascensão na escala de fruição dos bens culturais e para realizar a sua tendência a autonomia crescente.

A coerção no processo educativo deveria estar presente não para tolher os indivíduos, mas para discipliná-los, no sentido de oferecer uma condição necessária ao aprendizado. Só por meio de uma educação séria e ampla é que o indivíduo teria condições de ser um sujeito autônomo em todas as esferas sociais. Portanto, o processo de formação não se daria de modo casual e fácil, mas com seriedade, dedicação e, consequentemente, disciplina.

As regras e as normas não impedem o desenvolvimento da autonomia do sujeito, pelo contrário, elas possibilitam - aliadas ao rigor e à disciplina - a construção de consciência, assim como de um espaço de atuação da autonomia individual no seio da sociedade.

É evidente que as regras e normas não podem ser postas acima dos homens e das circunstâncias, ou seja, não são imutáveis. São construções históricas e requerem reelaborações constantes para acompanhar as necessidades de cada momento histórico.

Para Gramsci (2007, p. 1.706-1.707),

A disciplina não anula, portanto, a personalidade em sentido orgânico, mas apenas limita o arbítrio e a impulsividade irresponsáveis, para não falar da fátua vaidade de sobressair. [...] A disciplina, portanto, não anula a personalidade e a liberdade: A questão "personalidade e 
liberdade" se apresenta não em razão da disciplina, mas da "origem do poder que ordena a disciplina”. Se esta origem for "democrática”, isto é, se a autoridade for uma função técnica especializada e não "arbítrio" ou imposição extrínseca e exterior, a disciplina é um elemento necessário de ordem democrática, de liberdade.

Evidencia-se, desse modo, a correlação que Gramsci estabelece entre disciplina e responsabilidade, porque não é possível viver em sociedade se todos os indivíduos fizerem absolutamente o que as suas paixões incitam. Corrobora-se, com essa perspectiva, a visão da educação como um processo complexo que exige compromisso, disciplina e determinação de todos os sujeitos envolvidos. Um processo sério que não deve ser facilitado em detrimento da mais ampla e completa formação humanista e intelectual.

É nesse âmbito que Gramsci reconhece os méritos da escola clássica e do ensino de latim e grego, pois "exigia disciplina mental, dava formação civil e possibilitava formar a consciência histórica” (Jesus, 1998, p. 71).

Em suas palavras:

O latim não é estudado para aprender o latim; o latim, há muito tempo, graças a uma tradição cultural-escolar da qual se poderia pesquisar a origem e o desenvolvimento, é estudado como elemento de um programa escolar ideal, elemento que se resume e satisfaz toda uma série de exigências pedagógicas e psicológicas; é estudado para que as crianças se habituem a estudar de determinada maneira, a analisar um corpo histórico que pode ser tratado como um cadáver que continuamente volta à vida, para habituá-las a raciocinar, a abstrair esquematicamente (mesmo que sejam capazes de voltar da abstração à vida real imediata), a ver em cada fato ou dado o que há nele de geral e de particular, o conceito e o indivíduo. [...] Esse estudo educava sem ter a vontade expressamente declarada de fazê-lo, com uma mínima intervenção "educativa" do professor: educava porque instruía. (Gramsci, 2007, p. 1.545-1.546). 
Depreende-se desse trecho um ponto que também deve ser levado em consideração no processo de aprendizagem - além dos conteúdos ministrados e da intenção de abordá-los, ou seja, de que tipo de homem se pretende formar -, e esse ponto é a construção do lugar social de estudante. É preciso adquirir atitudes, procedimentos e transformá-los em hábitos para que o sujeito consiga lidar e construir saberes, mais do que recebê-los de modo passivo.

Gramsci defendia o estudo do latim e do grego e, mais do que isso, via nesses estudos um viés formativo de fato e não simplesmente instrutivo, pois enxergava a significância na possibilidade de apreensões e construções com base nos esquemas de abstração e de manipulação entendidos com um produto histórico.

Isto não significa (e seria tolice pensá-lo) que o latim e o grego, enquanto tais, tenham qualidades intrinsecamente taumatúrgicas no campo educativo. É toda a tradição cultural, que vive também e, sobretudo, fora da escola, que produz - num ambiente determinado - estas consequências. Vê-se, de resto, como modificada a tradicional intuição da cultura, tenha a escola entrado em crise e o estudo do latim e do grego entrado igualmente em crise. (Gramsci, 2007, p. 1.546).

Deduz-se dessa passagem o apreço que Gramsci tinha ao passado e à tradição cultural. É preciso resgatar do passado o que ele tem de bom para não só construir o "hoje”, como o "amanhã”.

No Caderno 10 encontra-se outro trecho que também elucida a valoração que Gramsci designava ao passado:

Cada grupo social tem uma "tradição", um "passado", e põe este como o único e total passado. Aquele grupo que compreendendo e justificando todos esses "passados", saberá identificar a linha de desenvolvimento real, por isso contraditória, mas na contradição passível de superação, cometerá "menos erros", identificará mais elementos "positivos" sobre os quais apoiar a alavanca para criar uma nova história (Gramsci, 2007, p. 1.354). 
Justamente por sua visão historicista, Gramsci não renega o legado de épocas antecessoras. Considera de extrema importância utilizar-se do passado para aprender e construir novos feitos. $\mathrm{E}$ isso não apenas no que se refere às questões pedagógicas, mas em todos os aspectos que envolvem a vida dos sujeitos. Apropriar-se da bagagem histórica do homem é o primeiro passo para o desenvolvimento de um novo futuro, e é nesse sentido que a perspectiva educativa gramsciana é encaminhada.

Poder-se-ia dizer que a pedagogia gramsciana está entre a espontaneidade e a autoridade. Utilizando uma formulação aristotélica, dir-se-ia que seria o "justo-meio" 5 entre elas o que acarretaria a primazia da responsabilidade. Mas essa fórmula não é exata, pois Gramsci não está entre, mas vai além, superando a dicotomia entre espontaneidade e autoridade ao entender o processo educativo como passagem da anomia à autonomia pela mediação da heteronomia.

Como elucida Dermeval Saviani (2013, p. 76),

Contra as dicotomias automatismo versus criatividade, coerção versus liberdade, heteronomia versus autonomia, Gramsci mostra que só é possível ser criativo a partir do momento em que são incorporados determinados mecanismos; só é possível ser livre quando são absorvidas as imposições naturais e culturais que caracterizam a vida em sociedade; só se atinge a autonomia quando, ajudados pelos adultos no âmbito da sociedade e pelos professores no interior das escolas, as crianças e jovens superam o estado de anomia.

Certa dose de "coerção", de "dogmatismo", é necessária ao ensino das crianças, por exemplo, na escola primária. No Caderno 12, ao tratar de como acredita que deve se desenvolver a organização escolar, afirma: "O problema didático para resolver é aquele de moderar e fecundar a direção dogmática que não pode não ser própria desses primeiros anos" (Gramsci, 2007, p. 1.535).

${ }^{5}$ Formulação aristotélica. Para maiores informações: ARISTÓTELES. Ética a Nicômaco. São Paulo: Nova Cultural, 1987. (Coleção Os Pensadores).v. 2. 
O trecho abaixo é de uma correspondência destinada à mulher Giulia, datada de 14 de julho de 1930, e aponta para a questão da necessidade de certa dose de coerção na primeira infância:

O que escreve dos meninos é interessante e característico (escolhe muito bem as partes que possam me agradar), mas não me dá a ideia de um desenvolvimento, de um enriquecimento progressivo das suas pequenas vidas de homens em formação, da formação neles de uma embrionária concepção do mundo. O meu aceno no mapa geográfico tinha somente esse significado e não era um fato pedante, se bem que eu creio que com as crianças, até que a personalidade tenha atingido um certo grau de desenvolvimento, um pouco de pedantismo seja necessário e indispensável. (Gramsci, 1987a, p. 241).

Também em uma carta anterior, datada de 24 de março de 1930, escrita à cunhada Tatiana, ao dizer que gostaria de ajudá-la a melhorar seu estado de saúde, Gramsci aponta para a necessidade de acompanhar de perto esse processo e, em analogia com a educação das crianças, afirma: "precisaria estar próximo e empregar meios persuasivos como se faz com as crianças (e você sabe que eu entendo os sistemas educativos eficazes com um pouquinho de coerção também física)" (Gramsci, 1987a, p. 227).

Justamente porque a formação não se dá ao acaso e espontaneamente, é que a direção e o rigor são importantes, principalmente nessa etapa escolar, visto que as crianças ainda não dispõem de autonomia. A autonomia será construída, mas, para tal, há que se fazer uso da autoridade durante esse processo, o que enfatiza o papel insubstituível do professor.

Isso não significa que o processo educativo exercido com uso da autoridade passa pela simples conformação ou pela substituição de uma conformação por outra - quando convicções anteriores são substituídas por outras adquiridas pela ação dos professores. A autonomia dos sujeitos não é eliminada, mas garantida, e se convicções 
são geradas, não é de forma meramente receptiva, passiva, tomadas sem compreensão, reflexão e crítica.

Manacorda (1990) nos diz que, analogamente, Gramsci estabelece um paralelo entre a pedagogia e o Estado. A necessidade de um equilíbrio entre sociedade civil e sociedade política, no âmbito do Estado é, em nível macro, a mesma, em nível micro, no que se refere à pedagogia.

Ao Estado como equilíbrio entre sociedade política e sociedade civil, na dimensão universal, corresponde na dimensão molecular, pedagógica, o equilíbrio entre coerção e espontaneidade, que ele está buscando e que parece aflorar no conceito de responsabilidade. (Manacorda, 1990, p. 95).

Para Gramsci, seria inconcebível pensar a educação nos moldes rousseaunianos. Ele se opunha à ideia de instruir deixando as crianças entregues à sua natureza e interesse, permitindo que as construções e os saberes se desenvolvessem por si. Se a responsabilidade paira sobre os homens, paira sobre a escola e, portanto, não há como pressupor a educação sem diretividade.

Defensor da diretividade no processo educativo, Gramsci recorda que a valorização da espontaneidade e da criatividade em si mesmas pode ser ardilosamente a ressonância de vertentes conservadoras, resistentes à mudança, perpetuadas na suposta mentalidade espontânea. (Boto, 1996, p. 24).

Isso não significa, contudo, que essa direção será a inculcação de conteúdos e saberes, a mera transmissão do que se considera relevante, o que imediatamente também nos remete a indagação: relevante para quem e por quê? Se a diretividade não tiver um rumo claro em relação à construção de uma nova visão de mundo, a escola apenas reproduzirá e legitimará o caráter ideológico vigente no ensino. É preciso que, pela 
nova educação abraçada por Gramsci, se venham a construir outras referências: um modo de instruir e de educar comprometidos com a ação social, com a esfera pública, com o coletivo e, nesse sentido, com a emancipação humana.

\section{Proposta de organização escolar gramsciana}

Gramsci não apenas apontou a necessidade de uma escola de caráter unitário para todos, como se dedicou a elencar uma proposta de organização para essa escola que pleiteava.

Um ponto importante, no estudo da organização da escola unitária, é o que diz respeito ao currículo escolar em seus vários níveis, de acordo com a idade e o desenvolvimento intelectual-moral dos alunos e com os fins que a própria escola pretende alcançar. (Gramsci, 2007, p. 1.534).

Para ele, essas modificações precisariam ocorrer em todos os sentidos, incluindo o espaço físico da escola, como demonstra em um trecho do Caderno 12:

mas essa transformação da atividade escolar demanda uma enorme ampliação da organização prática da escola, isto é, dos edifícios, do material científico, do corpo docente, etc. (Gramsci, 2007, p. 1.534).

A escola única teria o trabalho como princípio educativo e comporia os níveis de ensino elementar e médio, no qual propunha, respectivamente, 3 a 4 e 5 a 6 anos, "de modo que aos 15-16 anos já deveriam estar concluídos todos os graus da escola unitária"(Gramsci, 2007, p. 1.535).

O nível elementar deveria abordar as noções instrumentais básicas da instrução, com o ensino de leitura, escrita, aritmética, geografia, história e as primeiras noções sobre direitos e deveres de 
todos os cidadãos, tratando, portanto, de questões sobre Estado e sociedade "enquanto elementos primordiais de uma nova concepção do mundo que entra em luta contra as concepções determinadas pelos diversos ambientes sociais tradicionais, ou seja, contra as concepções que poderíamos chamar de folclóricas” (Gramsci, 2007, p. 1.535).

$\mathrm{Na}$ concepção gramsciana, o ensino dessas questões sobre Estado e sociedade não tinha o espaço merecido e necessário dentro da escola. Se o desejado era a formação de um novo homem soberano, essas noções eram imprescindíveis e deveriam ser tratadas desde o ensino elementar. Apenas com esse tratamento seria possível a construção de uma nova concepção de mundo libertadora.

Gramsci chama a atenção para um elemento importante a ser considerado nessa proposta de organização escolar:

Pode-se dizer, porém, que o conjunto da nova organização deverá conter em si mesmo os elementos gerais que fazem com que, hoje, pelo menos para uma parte dos alunos, o curso seja muito lento. Quais são esses elementos? Em uma série de famílias, especialmente das camadas intelectuais, os jovens encontram na vida familiar uma preparação, um prolongamento e uma complementação da vida escolar, absorvendo no "ar", como se diz, uma grande quantidade de noções e de aptidões que facilitam a carreira escolar propriamente dita: eles já conhecem, e desenvolvem ainda mais, o domínio da língua literária, isto é, do meio de expressão e de conhecimento, tecnicamente superior aos meios de que dispõe a média da população escolar dos 6 aos 12 anos. [...] $\mathrm{Na}$ organização interna da escola unitária, devem ser criadas, ao menos, as principais dessas condições, além do fato, que se deve dar por suposto, de que se desenvolverá, paralelamente à escola unitária, uma rede de creches e outras instituições nas quais, mesmo antes da idade escolar, as crianças se habituem a uma certa disciplina coletiva e adquiram noções e aptidões pré-escolares. (Gramsci, 2007, p. 1.535-1.536).

Depreende-se que Gramsci considera que a aprendizagem 
e a formação do sujeito iniciam-se muito antes da sua entrada na escola, assim como não se encerra nesse espaço. Por esse motivo ele se preocupou com o fato de essa formação inicial da vida das crianças ser bastante desigual e destinou a isso um espaço em suas reflexões.

Em sua ótica, não era possível iniciar o processo de educação escolar pressupondo que todas as crianças chegam iguais à escola ou negando essa desigualdade existente. Se algumas chegam mais preparadas para o ensino sistemático de conhecimentos, valores, posturas, conceitos e outras não, é preciso cuidar para que todas adquiram condições mínimas para o prosseguimento, sem grandes dificuldades, dos estudos nessas instituições.

Além disso, esse trecho denota a preocupação que Gramsci destina a todos os aspectos envolvidos em uma instituição de ensino.

A "elevação cultural e moral" da classe trabalhadora começaria desde o princípio dos estudos, já na escola elementar. Por esse motivo, esse nível de ensino também necessitava passar por mudanças que abrissem espaço à abordagem de noções essenciais para o exercício da cidadania, para a construção de uma consciência de classe e, principalmente, para a edificação de um novo homem, capaz de tornar a revolução uma realidade.

De fato, a escola unitária deveria ser organizada como uma escola em tempo integral, com vida coletiva diurna e noturna, liberta das atuais formas de disciplina hipócrita e mecânica, e o estudo deveria ocorrer coletivamente, com a assistência dos professores e dos melhores alunos, mesmo nas horas do estudo dito individual etc. (Gramsci, 2007, p. 1.536).

Essa passagem elucida a preocupação que Gramsci tinha com a organização das instituições de ensino. Como a escola configurarse-ia no cerne das estratégias de ação formativa para a edificação da hegemonia popular - calço de uma nova estruturação social -, julgava plausível uma efetiva e completa reestruturação. Para atender à 
necessidade e responsabilidade de uma formação ampla e norteadora de todos os princípios capazes de fazer emergir o "homem novo", sujeito histórico-crítico e revolucionário, Gramsci acreditava que a escola unitária deveria ser em tempo integral, com atividades ocorrendo em todos os períodos do dia.

Além disso, pautava a participação ativa de todos os alunos inclusive na construção das atividades e no encaminhamento do currículo como um todo. Afinal, para formar um protagonista histórico era preciso deixar espaço para o exercício da autonomia, da reflexão e da crítica em todas as situações escolares, assim como em todos os outros espaços sociais. Nesse sentido, ressalta:

Criticar os programas e a organização disciplinar da escola significa menos do que nada, se não se levam em conta estas condições. Assim retorna-se à participação realmente ativa do aluno na escola, que só pode existir se a escola for ligada à vida. (Gramsci, 2007, p. 1.543).

A escola unitária seria responsável por mudanças profundas na sociedade, não apenas no âmbito pedagógico e de preparação para algum posto de trabalho.

No Caderno 8 e no Caderno 16, Gramsci destaca essa dimensão proferida pela escola e enfatiza seu caráter "obrigatório"6:

Com efeito, o fato de a instrução ser obrigatória não significa que se deva repudiá-la nem sequer que não se possa justificar, com

${ }^{6}$ A citação do Caderno 16 é do tipo C, foi, portanto, reescrita a primeira formulação (texto do tipo A), transcrita a seguir e encontrada no caderno 8: "Que a instrução seja 'obrigatória' não significa que se deva repudiá-la: precisa ser feito 'liberdade' daquilo que é 'necessário', mas para isso é necessário reconhecer uma necessidade 'objetiva', isto é, que seja objetiva também para um grupo em questão. Necessita, portanto, referir-se às relações técnicas de produção, a um determinado tipo de produção que para ser continuado e desenvolvido requer um determinado modo de viver e, portanto, determinadas regras de conduta". (Gramsci, 2007, p. 1.033). 
novos argumentos, uma nova forma de obrigatoriedade: é preciso transformar em "liberdade" aquilo que é "necessário", mas para tanto é preciso reconhecer uma necessidade "objetiva”, isto é, que seja objetiva precipuamente para o grupo em questão. Por isso, é preciso referir-se às relações técnicas de produção, a um determinado tipo de civilização econômica que, para ser desenvolvido, requer um determinado modo de viver, determinadas regras de conduta, um certo costume. (Gramsci, 2007, p. 1.875-1.876).

A escola existente na Itália auxiliava na manutenção da ordem vigente, perpetuava as desigualdades, legitimava um modo de ver e de se relacionar com o mundo que impedia uma mudança no sistema e acabava por reforçar a estratificação social e todos os artifícios necessários para mantê-la. Gramsci se refere no trecho acima à importância de se ter consciência desse processo, do papel mantenedor ou transformador da escola. Era preciso cuidar atentamente de todos os detalhes que envolviam a construção de um ensino emancipador, principalmente na esfera das relações entre os membros envolvidos. Além disso, ele enfatiza que a obrigatoriedade do ensino não constitui uma estratégia de coação, mas uma necessidade para a construção da consciência e da liberdade.

As transformações geradas por essa proposta escolar farse-iam sentir, principalmente, no exterior da escola, nas relações humanas, na maneira como a realidade seria vista, na clareza de outras possibilidades de ação.

O trabalho como princípio educativo da escola única não seria restrito aos níveis elementar e médio, mas também ao nível superior; portanto, não seria uma etapa da formação escolar dos sujeitos, mas o pilar da formação integral do indivíduo, tendo em vista sua relação intrínseca com a vida social.

A escola média deveria estar organizada de modo a dar continuidade e aprofundamento ao trabalho desenvolvido na etapa elementar, não apenas dando sequência à hierarquia de conteúdos, mas, 
principalmente, ao trato de questões e valores essenciais e compatíveis com uma nova sociedade.

Entretanto, Gramsci aponta que um dos problemas existentes na escola vigente é a discrepância entre o ensino médio e liceu e o ensino superior, no sentido de que:

Do ensino quase puramente dogmático, no qual a memória desempenha um grande papel, passa-se à fase criadora ou de trabalho autônomo e independente; da escola com disciplina de estudo imposta e controlada autoritariamente, passa-se a uma fase de estudo ou de trabalho profissional na qual a autodisciplina intelectual e a autonomia moral são teoricamente ilimitadas. E isso ocorre imediatamente depois da crise de puberdade, quando o ardor das paixões instintivas e elementares não tem ainda terminado de lutar com os freios do caráter e da consciência moral em formação. $\mathrm{Na}$ Itália, além disso, onde nas Universidades não é difundido o princípio do trabalho de "seminário", a passagem é ainda mais brusca e mecânica. (Gramsci, 2007, p. 1.536).

Essa distinção no modo de concepção e no método de condução do ensino nesses diferentes níveis gerava a dificuldade que os jovens apresentavam de serem autônomos, participativos e criativos. A esse respeito, Gramsci destaca no Caderno 12: "o discente não é um disco de gramofone, não é um recipiente passivamente mecânico, ainda que a convencionalidade litúrgica dos exames assim o faça parecer por vezes" (Gramsci, 2007, p. 1.549).

Nesse trecho, Gramsci também revela uma crítica ao modo como as avaliações eram realizadas nas escolas, com a intenção de testar conteúdos, o que, na sua interpretação, não prova nada. Afinal:

prestar um exame, hoje, deve ser mais um "jogo de azar" do que antigamente. Uma data é sempre uma data, qualquer que seja o professor examinador, e uma "definição" é sempre uma definição; 
mas e um julgamento, uma análise estética ou filosófica?” (Gramsci, 2007, p. 1.543).

Conduzir avaliações como instrumentos meramente probatórios de assuntos, de forma isolada, não traz resultado algum para a constituição de alunos criativos, reflexivos, autônomos e críticos. Era preciso que as avaliações fossem condizentes com esse ideal de formação, que realmente problematizassem e fossem instigantes ferramentas de aprendizagem. Afinal, como se esperar a criação de quem nunca teve a oportunidade de exercitar essa capacidade? Como esperar a criatividade e o protagonismo do jovem no ensino superior se ele não pode sequer aparecer de fato durante o processo de formação anterior?

Era crucial que o ensino médio fosse conduzido de modo a possibilitar o livre exercício investigativo, prático e criativo dos sujeitos. Como salienta Gramsci (2007, p. 1.537),

O estudo e a aprendizagem dos métodos criativos na ciência e na vida devem começar nessa última fase da escola, não devendo ser mais um monopólio da universidade ou ser deixado ao acaso da vida prática: esta fase escolar já deve contribuir para desenvolver o elemento da responsabilidade autônoma nos indivíduos, deve ser uma escola criadora.

O ensino médio prepararia os indivíduos para a profissão que eles optassem por desempenhar na sociedade, mas, mais do que isso, conduziria o homem a uma atuação consciente e transformadora.

Gramsci (2007, p. 1.548) também afirma a importância do ensino de filosofia, "um novo curso pedagógico", principalmente para os estudantes que não haviam recebido ajuda intelectual fora da escola (a maioria). Assim,

A filosofia descritiva tradicional, reforçada por um curso de história da filosofia e pela leitura de um certo número de filósofos, praticamente 
parece ser a melhor coisa. A filosofia descritiva e definidora será uma abstração dogmática, como a gramática e a matemática, mas é uma necessidade pedagógica e didática. $1=1$ é uma abstração, mas ninguém é por isso conduzido a pensar que 1 mosca é igual 1 elefante. Também as regras da lógica formal são abstrações do mesmo gênero, são como a gramática do pensar normal, contudo, é necessário estudá-las, porque não são inatas, devem ser adquiridas com o trabalho e a reflexão. (Gramsci, 2007, p. 1.549).

Esse nível de ensino tinha como função primordial "criar os valores fundamentais do humanismo", a autonomia moral e a autodisciplina intelectual "necessárias a uma posterior especialização, seja ela de caráter científico (estudos universitários), seja de caráter imediatamente prático-produtivo (indústria, burocracia, organização comercial etc.)”.(Gramsci, 2007, p. 1536-1537). Ou seja, independente do ramo profissional a ser seguido, o jovem deveria estar preparado para lidar com as questões que competiam à sua vida e à da sociedade em que estava inserido, não de modo passivo, mas de maneira atuante nesse mundo.

A escola média estava atrelada ao projeto de escola unitária de Gramsci e compunha, juntamente com os demais preceitos de organização cultural, a estratégia de ação na formação da classe trabalhadora como classe capaz de se tornar dirigente.

Nesse sentido, não seria apenas uma escola ativa, mas uma escola criativa:

A escola criadora é o coroamento da escola ativa: na primeira fase, tende-se a disciplinar e, portanto, também a nivelar, a obter uma certa espécie de "conformismo" que pode ser chamado de "dinâmico"; na fase criadora, sobre a base atingida de "coletivização" do tipo social, tendese a expandir a personalidade, tornada autônoma e responsável, mas com uma consciência moral e social sólida e homogênea. Assim, escola criativa não significa escola de "inventores e descobridores"; indica-se 
uma fase e um método de investigação e de conhecimento, e não um "programa” predeterminado que obrigue à inovação e à originalidade a todo custo. (Gramsci, 2007, p. 1.537).

Essa passagem elucida o espaço que Gramsci considera como indispensável à atividade de pesquisa como instrumento valiosíssimo para o alcance dos conhecimentos e do repertório, para o exercício da autonomia dos alunos, não apenas no espaço escolar, mas nos demais ambientes sociais.

A escola criativa, na acepção gramsciana, indica que a aprendizagem se solidifica especialmente por um esforço autônomo do aluno, de modo que o papel que o professor exerce, embora indispensável, é o de um guia e não o de um controlador e transmissor de saberes. O "coroamento" dessa escola criativa se dá na universidade. Afinal,

Descobrir por si mesmo, sem sugestões e ajudas externas, uma verdade é criação, também se a verdade é velha, e demonstra a posse do método; indica que de todo modo se adentrou na fase da maturidade intelectual na qual se podem descobrir verdades novas. Por isso essa fase da atividade escolar fundamentalmente se realizará nos seminários, nas bibliotecas, nos laboratórios experimentais [...]. (Gramsci, 2007, p. 1.537-1.538).

Esse apreço à investigação e à pesquisa corrobora a visão gramsciana de educação e do homem que se pretende formar com ela. Gramsci destaca os espaços em que é possível estabelecer trocas, discussões, debates com outros sujeitos, assim como os ambientes mais propícios à atividade investigativa, porque concebe o aprendizado como uma construção e não como transmissão de saberes que pode ser reduzida ao ditar conteúdos nas salas de aula, sem possibilidade efetiva de interlocução e ação dos alunos.

Entretanto, dar espaço à criação na escola não significa negar 
ou diminuir o papel da instrução e do rigor no processo de ensinoaprendizagem, não significa deixar o aluno "reinventar a roda", como afirma Boto:

Ensino não é pesquisa; aprender não é desvendar um vazio. Escola criativa, portanto, é aquela que, ensinando, induz o estudante a guiarse cada vez mais de maneira autônoma para que, ao fim do processo, seu aprendizado possa existir independentemente da ação escolar. (Boto, 1996, p. 26).

Gramsci (2007, p. 1.538) também salienta que "os elementos sociais empregados no trabalho profissional não devem cair na passividade intelectual”. Devem, pelo contrário, ter à sua disposição institutos especializados em todo tipo de pesquisa e de trabalho científico que possam colaborar com o enriquecimento formativo e com qualquer atividade de ordem cultural que se queira desenvolver. Por isso,

A organização acadêmica (deverá ser) reorganizada e vivificada de uma ponta a outra. Territorialmente haverá uma centralização de competências e de especializações: centros nacionais que se agregarão as grandes instituições existentes, seções regionais e provinciais e círculos locais urbanos e rurais. Será dividida por competências científico-culturais, que serão todas representadas nos centros superiores, mas só parcialmente nos centros locais. Unificar os vários tipos de organização cultural existente: Academias, Institutos de cultura, círculos filológicos, etc., integrando o trabalho acadêmico tradicional, que se explica prevalentemente na sistematização do saber passado ou na tentativa de estabelecer uma média do pensamento nacional como guia da atividade intelectual, com atividade coligada à vida coletiva, ao mundo da produção e do trabalho. (Gramsci, 2007, p. 1.538-1.539). 
Esse trecho evidencia como Gramsci enxergava, na organização da escola, um caminho de suma importância para a viabilização de uma "reforma cultural e moral". Mais do que cuidar dos conteúdos que seriam ministrados nas instituições de ensino, era primordial ter um plano integral e unitário que abrangesse todos os outros espaços formativos e culturais da sociedade em prol de uma intenção única: criar o homem capaz de fazer da revolução social e política uma realidade concreta. É por isso que, na sequência do texto, destaca:

Será construído um mecanismo para selecionar e fazer avançar as capacidades individuais da massa popular, que hoje são sacrificadas e se perdem em erros e tentativas sem saída. Cada círculo local deverá ter necessariamente a seção de ciências morais e políticas, e passo a passo organizará as outras seções especializadas para discutir os aspectos técnicos dos problemas industriais, agrários, de organização e racionalização do trabalho, de fábrica, agrícola, burocrático, etc. [...]

A colaboração entre esses organismos e a Universidade deveria ser estreita, assim como com todas as escolas superiores especializadas de cada gênero (militares, navais, etc.). O objetivo é de obter uma centralização e um impulso da cultura nacional que seriam superiores àqueles da Igreja Católica. (Gramsci, 2007, p. 1.539).

Essa passagem trata da ligação intrínseca que a escola deveria desenvolver também com os círculos de cultura, justamente para empreender a elevação cultural e moral dos sujeitos. As instituições formais de ensino não poderiam estar segregadas dos outros espaços formativos, sendo indispensável à construção dessa ligação, que deveria ser estendida até a universidade. Todos os organismos destinados à formação dos indivíduos deveriam ter a mesma intenção e encaminhamento para possibilitar a emancipação real das pessoas. Por isso, Gramsci não abria mão da unidade entre eles e exemplificava e justificava essa importância, apontando para os organismos da Igreja 
Católica, que não teriam o poderio e a influência que têm se não tivessem essa intenção e unidade.

Gramsci também se preocupou com questões que tocam a universidade, que seria o cume da nova organização pretendida para a escola e a cultura aos trabalhadores, sempre encadeada com seu projeto de revolução.

A universidade italiana da época, como a organização geral da escola, apresentava um caráter de casta, como destaca Gramsci no Caderno 16:

A universidade é a escola da classe (e do pessoal) dirigente propriamente dito, é o mecanismo através do qual ocorre a seleção dos indivíduos das outras classes a serem incorporados ao pessoal governativo, administrativo e dirigente. (Gramsci, 2007, p. 1.868).

Era preciso que a universidade deixasse de ter esse caráter. $\mathrm{Na}$ acepção gramsciana, a universidade constituiria a conclusão da escola unitária e, como tal, deveria estar a serviço e ao alcance de todos os sujeitos e não permanecer um lócus de segregação de classes, do conhecimento e, em certa medida, também do poder.

Já em um artigo escrito em 1916, intitulado "Universidade popular”, Gramsci (1973) apresenta um modelo de universidade que, diferentemente da mantida pelo Estado para os operários em Turim, por exemplo, deveria ser um "fogo vivo" capaz de promover verdadeiramente uma experiência rica e libertadora pela possibilidade fecunda de produzir conhecimentos e de não se cercar de preceitos referenciados como absolutos.

Gramsci criticava o modo como a universidade estava organizada, com relações entre ensino e pesquisa pautadas em experiências personificadas e isoladas. $\mathrm{O}$ incentivo a pesquisa e extensão não deveria limitar-se a iniciativa pessoal de alguns professores.

A universidade deveria ser o ambiente de maior veiculação e vivência de cultura; um espaço para a criação e não apenas para 
a reprodução e legitimação de preceitos circunscritos às gerações anteriores. Deveria ser realmente o "fogo vivo" pregado por Gramsci, a chama capaz de fomentar novas ações emancipadoras de todos os sujeitos, capaz de reinventar novas formas de se relacionar com a natureza, com as pessoas e com o mundo, o veículo capaz de formar sujeitos autônomos o suficiente para construir novas relações políticas, econômicas e sociais.

No Caderno 15, chamando a atenção para a questão do método, Gramsci, utilizando-se também de uma citação do livro do cardeal John Henry Newman, Lectures and essays on university subjects, destaca:

O método que a disciplina universitária prescreve para cada forma de pesquisa é bem outro e bem outro é o resultado: é a "formação do intelecto, isto é um hábito de ordem e de sistema, o hábito de reportar cada conhecimento novo àqueles que possuímos, e de ajustá-los em conjunto, e, o que mais importa, a aceitação e uso de certos princípios, como centro de pensamento[...]. Lá onde existe uma tal faculdade crítica, a história não é mais um livro de contos, nem a biografia um romance; os oradores e as publicações do dia perdem a infalibilidade; a eloquência não se equipara mais ao pensamento, nem as afirmações audazes ou as descrições coloridas assumem o lugar de argumentos". (Gramsci, 2007, p. 1.806). ${ }^{7}$

Para o autor, a promoção do espírito crítico e investigativo é prérequisito para a elaboração de uma nova realidade e para a perpetuação de uma nova visão de mundo, promulgadora de uma outra ordem social, política e econômica. Por essa razão, assinala que a universidade:

${ }^{7}$ O volume 4 da edição crítica dos Quaderni del carcere, organizado por Valentino Gerratana, contém a seguinte nota: "Os trechos resumidos ou citados do livro do cardeal John Henry Newman, Lectures and Essays on University subjects, são extraídos de um artigo de Fermi, Il Cardinale di Oxford, publicado em dois fascículos in 'Gerarchia', março 1933 (ano XIII, n.3), pp.245-50, e abril 1933 (n.4), pp.335-45; cfr em particular o fascículo de abril, pp.339-40”. (Gramsci, 2007, p. 2.951). 
Antes de tudo e em linha generalíssima, tem a tarefa humana de educar os cérebros para pensar de modo claro, seguro e pessoal, libertando-o das névoas e do caos nos quais uma cultura inorgânica, pretensiosa e confusa ameaçava submergi-lo [...]. (Gramsci, 2007, p. 1.806).

No Caderno 6, Gramsci enfatiza essa perspectiva com relação ao ensino universitário:

Um curso universitário é concebido como um livro sobre o assunto: mas alguém pode se tornar culto com a leitura de um só livro? Trata-se, portanto, da questão do método no ensino universitário: na Universidade se deve estudar ou estudar para saber estudar? Deve-se estudar os "fatos" ou o método para estudar os "fatos"? A prática do "seminário" deveria exatamente complementar e vivificar o ensino oral. (Gramsci, 2007, p. 844).

O ensino universitário deveria primar por semear críticos pesquisadores, por fomentar sujeitos capazes de lidar com os conhecimentos historicamente acumulados de forma autônoma, inventiva e, para isso ser possível, o método teria que ser compatível com a proposta. Afinal, não se ensina a ser livre criador sem tornar esse exercício possível ainda no processo de formação.

\section{Considerações finais}

A questão educativa apresenta-se como o cume na perspectiva gramsciana, justamente pelo caráter fundante da transformação necessária para a construção de uma nova ordem social.

A escola única seria a materialização maior do projeto educativo revolucionário de Gramsci. Uma escola de formação humanista, que oferecesse o mesmo ensino a todos os sujeitos, que não fosse guiada por interesses classistas.

$\mathrm{O}$ espontaneísmo como princípio pedagógico era negado. $\mathrm{O}$ 
processo de formação de uma nova concepção de mundo não poderia ser relegado ao acaso, à inspiração e à vontade individual, justamente porque exigia um percurso árduo, difícil e longo de muito trabalho e empenho. A diretividade é fundamental para a conquista da autonomia e para a formação integral do sujeito.

Exatamente porque seu projeto educativo tinha em si o peso de um plano de total reconstrução social é que Gramsci não poderia permitir que o ensino fosse menos do que poderia ser. $\mathrm{O}$ novo homem deveria ter um preparo que incluísse não apenas o mais amplo repertório de conhecimentos historicamente acumulados pela sociedade, mas a estimulação à reflexão, ao exercício crítico e criativo diante do referido repertório.

As análises de Gramsci não se pulverizam no particularismo da época por ele vivida. Se as suas reflexões e proposições ainda incitam possibilidades para a realização da mais árdua e importante tarefa de educar os homens - diante dos dilemas e problemáticas sociais, políticas, econômicas e naturais do nosso mundo - e, mais do que isso, suscitam indagações cabíveis ao nosso cotidiano e realidade, é porque seu pensamento traduz uma problemática humana atemporal: a constituição do homem como tal.

\section{Referências}

ARISTÓTELES. Ética a Nicômaco. São Paulo: Nova Cultural, 1987. (Coleção Os Pensadores).v. 2.

BOTO, Carlota. A pedagogia sob o signo da política: Gramsci educador. Didática (Revista Científica da Unesp), São Paulo, v. 31, 1996, p. 21-27.

DAL RI, Neusa Maria; VIEITEZ, Candido Giraldez. Trabalho educativo como princípio educativo e práxis político-pedagógica. In: MENDONÇA, Sueli Guadelupe de Lima; SILVA, Vandei Pinto da; MILLER, Stela. Marx, Gramsci e Vigotski: aproximações. Araraquara, SP: Junqueira \& Marin/Marília, SP: Cultura Acadêmica, 2009, p. 253-305.

FERREIRA, Oliveiros S. Os 45 cavaleiros húngaros: uma leitura dos Cadernos de Gramsci. São Paulo: Hucitec/Brasília: UnB, 1986.

GRAMSCI, Antonio. 2000 pagine di Gramsci. I Nel tempo della lotta (1914- 
1926). Volume Primo. A cura di Giansiro Ferrata e Niccolò Gallo. Milano: Casa editrice Il Saggiatore, 1964.

GRAMSCI, Antonio. Scritti politici. A cura di Paolo Spriano. Roma: Editori Riuniti, 1973.

GRAMSCI, Antonio. Lettere del carcere. Roma: Editrice L'Unità, 1987a. v. 1.

GRAMSCI, Antonio. Lettere del carcere. Roma: Editrice L'Unità, 1987b. v. 2.

GRAMSCI, Antonio. Quaderni del carcere. Edizione critica. 3. ed. A cura di Valentino Gerratana. Torino: Einaudi, 2007. 3.v.

JESUS, Antonio Tavares de. O pensamento e a prática escolar de Gramsci. Campinas: Autores Associados, 1998.

MANACORDA, M. A. O principio educativo em Gramsci. Porto Alegre: Artes Médicas, 1990.

SAVIANI, Dermeval. Gramsci e a educação no Brasil. In: LOMBARDI, José Claudinei; MAGALHÃES, Lívia D. R; SANTOS, W. S. (Orgs.). Gramsci no limiar do século XXI. Campinas: Editora Librum; Navegando Publicações, 2013, p. 61-80.

SILVA, Deise Rosalio. Intelectuais, cultura e escola única no pensamento politicopedagógico de Antonio Gramsci. 2010. 267f. Dissertação (Mestrado em Educação) - Faculdade de Educação, Universidade de São Paulo, São Paulo, 2010. 